\title{
RETRACTED ARTICLE: Field measurements and neural network modeling of water quality parameters
}

\author{
Afishin Qishlaqi $^{1} \cdot$ Sediqeh Kordian $^{1} \cdot$ Abbas Parsaie $^{2}$
}

Received: 1 May 2016/Accepted: 31 August 2016/Published online: 9 January 2017

(c) The Author(s) 2017. This article is published with open access at Springerlink.com

The Editor-in-Chief and the publisher have decided to retract this article due to the lack of getting permission from Regional Water Authority of Lorestan Province (Iran) for publishing information present in the manuscript.

The online version of this article contains the full text of the retracted article as electronic supplementary material.
Open Access This article is distributed under the terms of the Creative Commons Attribution 4.0 International License (http:// creativecommons.org/licenses/by/4.0/), which permits unrestricted use, distribution, and reproduction in any medium, provided you give appropriate credit to the original author(s) and the source, provide a link to the Creative Commons license, and indicate if changes were made.

Electronic supplementary material The online version of this article (doi:10.1007/s13201-016-0513-1) contains supplementary material, which is available to authorized users.

\footnotetext{
Abbas Parsaie

Abbas_Parsaie@yahoo.com

Afishin Qishlaqi

qishlaqi@shahroodut.ac.ir

Sediqeh Kordian

Kordian_S@yahoo.com

1 Environmental Geology Department, Geology College,

Shahrood University, Shahrud, Semnan, Iran

2 Lorestan University, Khorramabad, Iran
} 